\title{
Tomasz Stoeck
}

dr inz.

Adiunkt w Katedrze Eksploatacji Pojazdów Samochodowych

Zachodniopomorskiego Uniwersytetu Technologicznego w Szczecinie

tstoeck@wp.pl

\section{Wawrzyniec Golębiewski \\ dr inz.}

Adiunkt w Katedrze Eksploatacji Pojazdów Samochodowych

Zachodniopomorskiego Uniwersytetu Technologicznego w Szczecinie

wawrzyniec.golebiewski@wp.pl

DOI: 10.35117/A_ENG_16_06_03

\section{Rating preferences and transport behavior of passengers traveling to the Airport Szczecin-Goleniów}

\begin{abstract}
The article presents the results of a survey aimed at isolating the differences in preferences and behaviour of decision travellers commuting from Szczecin to Goleniów airport. Based on the data obtained a comparative analysis of the available means of transport, paying attention to the shortcomings of existing forms of transfer and possible ways of their elimination. Also the demands most frequently put forward and the opinions not included in the questionnaire but being reported during the whole survey were taken into consideration. Final results are presented in graphical and tabular form.
\end{abstract}

Keywords: Airport; Intermodal transport; Transport preferences.

\section{Introduction}

Modern airports are seen as catalysts of economic growth, because they assist the processes of economic development and have a significant impact on the investment attractiveness of different regions. Their modality is considered on many levels, including in the aspect of transport accessibility. Since the vast majority of airports are located at a distance from the centers of cities, travellers should be given a fast, direct and comfortable access to their land, assuming certain behaviour and individual communication preferences. For this reason, optimization, coordination and creating new connections with existing increases the impact area airports (catchment area), significantly affecting the increase in passenger traffic. Currently, a standard option is trucking, mainly due to a well-developed network of roads and motorways. National and foreign experiences indicate, however, that the improvement of access should also be effected by railway $[2,3,5,6,9]$. This is due to several factors, the most important from the point of view of passenger service are: short travel time, safety and driving comfort, low cost, high punctuality, easy access for the disabled. However, the anticipated increase in demand for this mode of transport requires offering competitive transport service, fully adapted to the needs and requirements of potential customers. Moreover, cooperation of railway transporters with air operators, brings a much wider benefits, reducing congestion on routes, the consumption of fossil fuels and noise and harmful emissions from the road. Providing the modality aims not only to strengthen the role and improve the accessibility of airports, but also to improve their competitiveness and capacity of transport. 


\section{Characteristics of Solidarity Szczecin-Goleniów Airport}

The largest airport in West Pomerania is registered in the system of the European Transport Network TEN-T. This international airport is located $45 \mathrm{~km}$ north-east of the center of Szczecin. It has good connections with the capital of West Pomeranian Province through the national road No. 6 and S3 expressway, and from 2013 the railway upon completion bus Airport Szczecin Goleniów and the section of track connected to the line 402. Its infrastructure allows receiving and handling of smaller passenger aircraft in all weather conditions. Over the years, the most important objects airports have been completely rebuilt and modernized, which has a definite impact on passenger traffic showing an upward tendency $[1,6,7,11]$. At present, however terminal with a throughput of 700-750 thousand people in a year is not used, even in half, what indicate substantial reserves and possibilities for further development (Figure 1). From planned investments it is worth mentioning the construction of a cargo airport and a special, which will focus on cooperation with regional seaports, as well as with national and foreign operators of TSL sector (Spedition-TransportLogistik). The main reason for such decision is the carriage of cargo and consignments, which since 2007 regularly falls $[8,11]$.

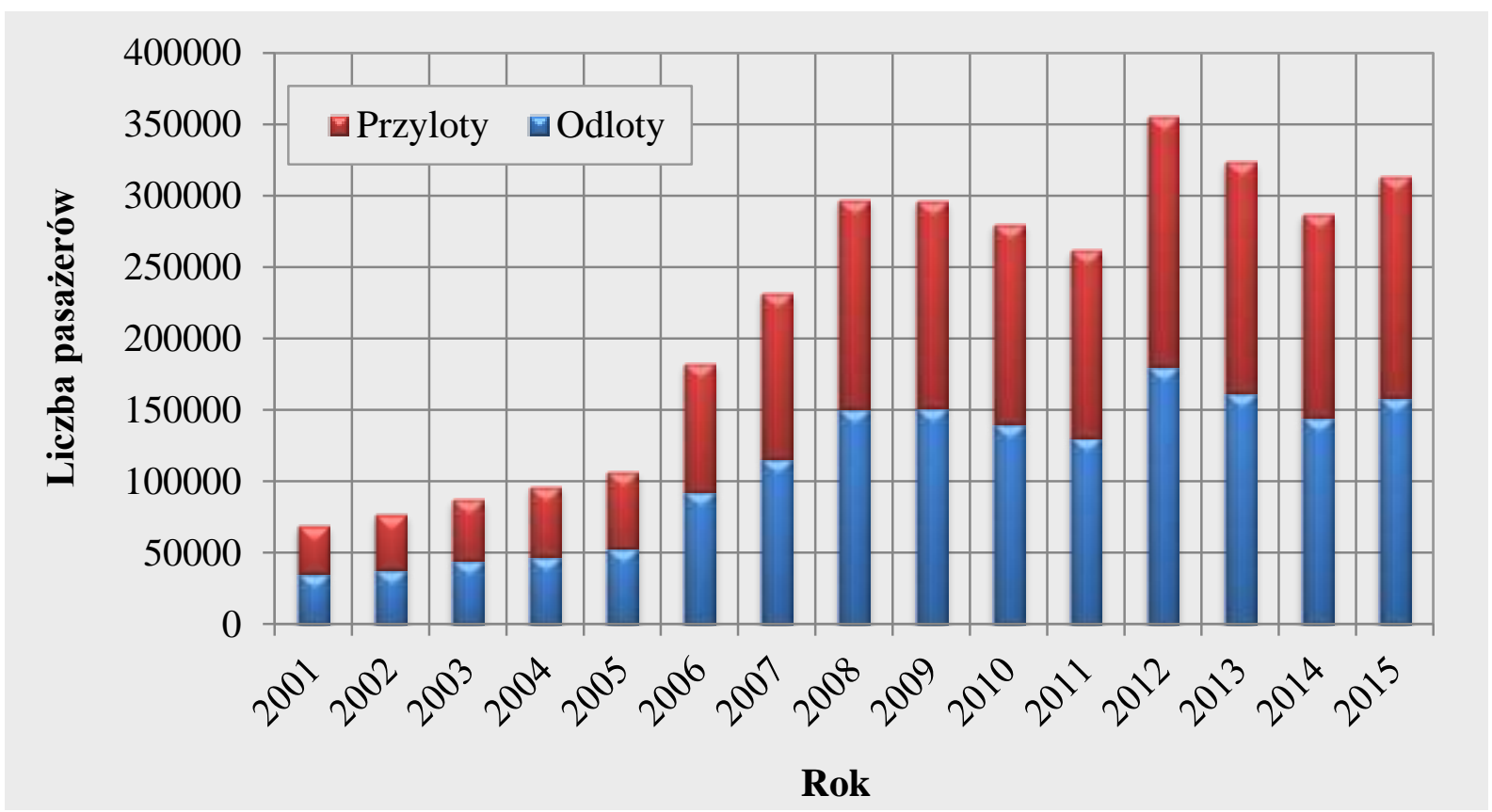

1. Passenger traffic at the airport Szczecin-Goleniów in years 2001-2015

Source: own compilation [11]

Changing preferences and directions of travel meant that in recent years, there were closed down a lot of domestic flights, and the dominant role is played by foreign flights (Table 1). Mainly it is because of economic factors, which are the predominant reason for the migration of the population in the European Union. At the decision-making behavior of passengers is principally affected the development of a network of motorways and express roads, which allows relatively quick and less expensive way to travel, including the not very far distant ferry crossings (Swinoujście, Sassnitz, Rostock). In addition, a noticeable improvement in the quality and comfort of travelling offer rail transporters, gradually upgrading existing network connections and exchanging the rolling stock in alternative aviation relationship long-distance. For these reasons we are looking for other alternatives, which are expected to increase passenger traffic at the airport Szczecin-Goleniów. An 
example may be irregular transports the so-called charter, carried out on behalf of tour operators and travel agencies in the winter season (Egypt) and summer season (Greece, Turkey).

Tab. 1. Directions and number of flights during the week from Airport Szczecin-Goleniów

\begin{tabular}{|c|c|c|c|c|c|}
\hline Lp. & $\begin{array}{c}\text { Port } \\
\text { docelowy }\end{array}$ & Dni realizacji kursu & Przewoźnik & Samolot & $\begin{array}{l}\text { Liczba odlotów w } \\
\text { ciągu tygodnia }\end{array}$ \\
\hline 1 & Warszawa & $\begin{array}{l}\text { Pn, Wt, Śr, Cz, } \\
\text { Pt, So, N }\end{array}$ & LOT & Bombardier Q400 & 19 \\
\hline 2 & Bergen & $\mathrm{Wt}$, So & Wizz & Airbus A320 & 2 \\
\hline 3 & Dublin & $\mathrm{Wt}$, So & Ryanair & Boeing 737-800 & 2 \\
\hline 4 & Liverpool & $\mathrm{Cz}, \mathrm{N}$ & Ryanair & Boeing 737-800 & 3 \\
\hline 5 & Londyn & $\begin{array}{l}\text { Wt, Śr, Cz, } \\
\text { So, N }\end{array}$ & $\begin{array}{l}\text { Wizz, } \\
\text { Ryanair }\end{array}$ & $\begin{array}{c}\text { Airbus A320, } \\
\text { Boeing 737-800 }\end{array}$ & 8 \\
\hline 6 & Oslo & $\begin{array}{l}\text { Pn, Wt, Śr, } \\
\mathrm{Pt}, \text { So, N }\end{array}$ & $\begin{array}{c}\text { Norwegian, } \\
\text { Ryanair, } \\
\text { Wizz }\end{array}$ & $\begin{array}{c}\text { Airbus A320, } \\
\text { Boeing 737-800 }\end{array}$ & 7 \\
\hline 7 & Stavanger & $\mathrm{Wt}$, So & Wizz & Airbus A320 & 2 \\
\hline \multicolumn{5}{|c|}{ Suma } & 43 \\
\hline
\end{tabular}

Source: own compilation [11]

\section{The scope and methodology}

The study was conducted at the turn of the year 2015/16 on a random sample of respondents. The aim was to determine the preferences and behaviour of decision-making that affect the choice of means of transport providing a direct connection between the center of Szczecin and the airport in Goleniów. The basic adopted tool was an anonymous questionnaire with ordered number of closed questions, so importing the answer to one of the identified variants. The research process conducted students of Transportation West Pomeranian University of Technology (ZUT) in Szczecin. Final results were developed on the basis of 620 correctly completed forms collected from travellers in the zone departures and arrivals of passenger terminal.

\section{A preferred mean of transport}

Data presented in Figure 2 shows that the most often chosen form of transfer is a private car. According to the respondents, it provides the most efficient way to travel, because it does not have the shortcomings characteristic of collective means of transport, i.e. does not set any time limit, lets you take any luggage and transfer to third parties without additional charge, allows for direct access to your destination without having to transfers and waiting at bus stops. In addition, refueling the vehicle can take place when completely unrelated to travel from / to the airport at a convenient form of payment for the buyer (cash, credit card, VAT invoice). In this group, nearly $2 / 3$ of respondents left the car on one of the two parking lots outside the terminal: red (hourly) or green (twenty-four seven), thereby agreeing to increase the total cost of travel. An interesting alternative to this solution is to use the taxi companies, 
which price is nearly ten times higher. For reservations call lengthens the total time to reach the airport, but there is a possibility to order services adapted to the needs of people with disabilities. Analogous results were obtained in the studies of similar profile, which results were presented in paper [6]. Despite the fact that since they started to carry out direct rail connections, this mean of transport is chosen is definitely sparsely. This was also reflected in response to a question about the reason for choosing a particular means of transport (Figure 3). Passengers appreciate much more ability to get directly to their destination in the shortest time, rather than driving comfort.

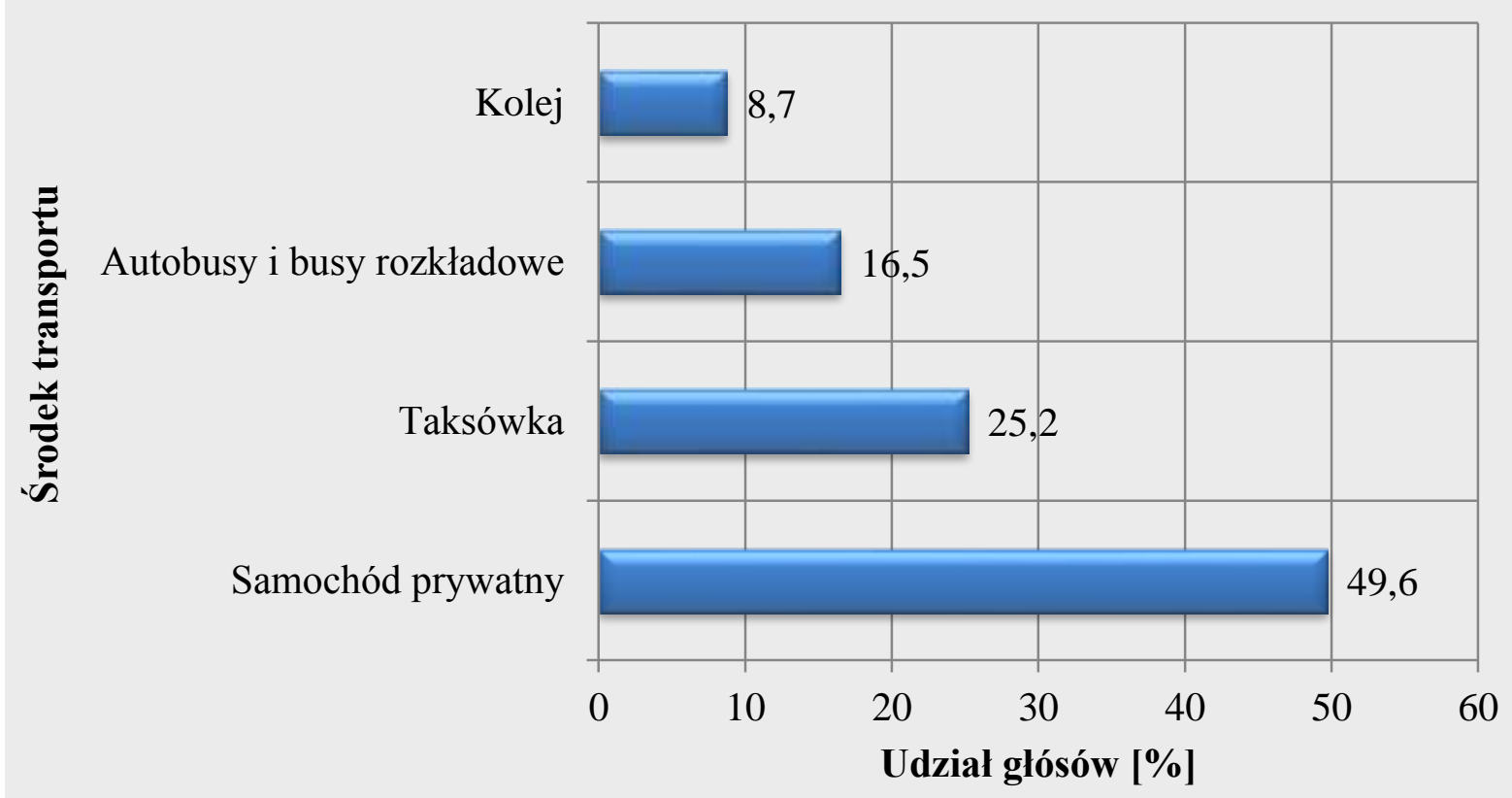

2. A preferred mean of transport to / from the Airport Szczecin-Goleniów Source: own compilation

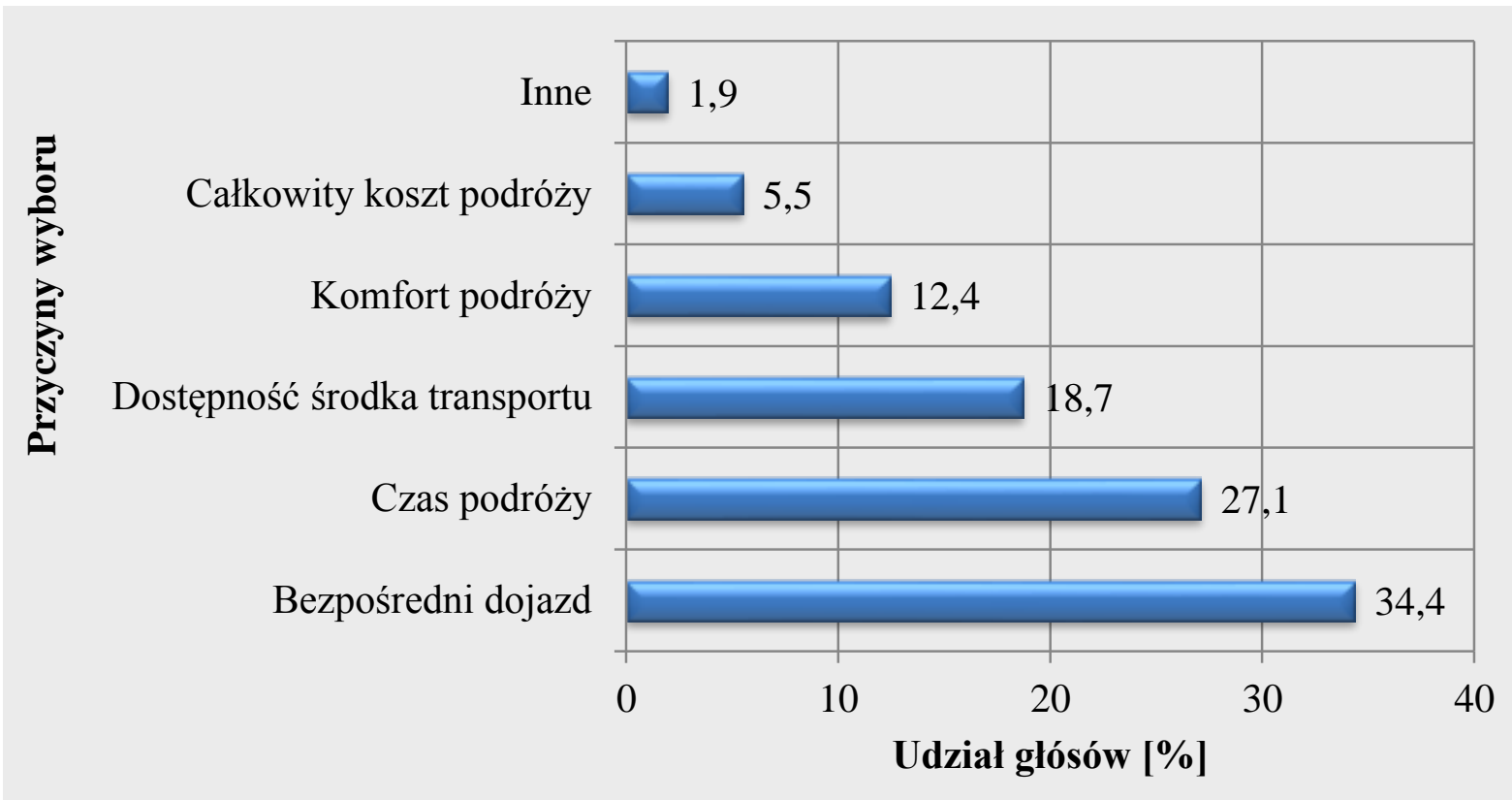

3. The reasons of choosing a particular mean of transport

Source: own compilation 


\section{Parameters of transportation}

Table 2 summarizes the parameters of the existing forms of transportation transfer. The place of departure / arrival adopted strict the city center, or Main Railway Station and its immediate surroundings, i.e. streets of Columbus, Św. Ducha or Wyzwolenia (passenger of the carrier LOT). Considering the presented data it can be seen that, in theory, the cheapest way to travel is by railways. Respondents emphasized, however, that incur additional charges related to the necessity of getting to / from the station, and in the case of non-use of ticket office also aid at the conductor of the train. Analogous difficulties affect people using buses and scheduled buses. In addition, collective vehicles stop at intermediate stops, characterizing the longest time to your destination. Reservations aroused also a small frequency of courses because railway connections are not matched with hours of arrival and departure of airplanes. This is mainly due to the marginal role of line 402 to operate passenger West Pomeranian Province, which offers regional connections Szczecin-Kołobrzeg. For these reasons, the respondents choose other means of transport, refusing to waive specific courses or too long waiting times. The share of votes cast for individual shortcomings access forms used are shown in Figure 4.

Tab. 2. Parameters of the existing forms of commuting

\begin{tabular}{|c|c|c|c|c|}
\hline \multirow[b]{2}{*}{$\begin{array}{l}\text { Parametry } \\
\text { przewozowe }\end{array}$} & \multicolumn{4}{|c|}{ Srodek transportu } \\
\hline & $\begin{array}{l}\text { Własny } \\
\text { pojazd }\end{array}$ & Taxi & Kolej & $\begin{array}{l}\text { Autobusy i busy } \\
\text { rozkładowe }\end{array}$ \\
\hline Czas dojazdu & ok. $37 \mathrm{~min}$ & ok. $37 \mathrm{~min}$ & $42-48 \mathrm{~min}$ & ok. $50 \mathrm{~min}$ \\
\hline Koszt dojazdu & $15,12 \mathrm{z}^{*}$ & $153 \mathrm{zl}$ & $\begin{array}{c}11,70 \mathrm{zł}(22,70 \mathrm{zł} \mathrm{w} \\
\text { pociągu) + dojazd do/z } \\
\text { dworca PKP }\end{array}$ & $\begin{array}{c}16,90 \mathrm{zł}(25 \mathrm{zł} \mathrm{w} \\
\text { pojeździe })+ \text { dojazd do/z } \\
\text { okolic dworca PKP lub } \\
\text { biura LOT }\end{array}$ \\
\hline Forma płatności & $\begin{array}{c}\text { Płatne w } \\
\text { dowolnym } \\
\text { momencie i } \\
\text { czasie } \\
\text { (gotówka } \\
\text { lub karta) }\end{array}$ & $\begin{array}{l}\text { Płatne u } \\
\text { kierowcy } \\
\text { (gotówka lub } \\
\text { karta) }\end{array}$ & $\begin{array}{c}\text { Płatne w kasie } \\
\text { biletowej lub w } \\
\text { pociągu (gotówka lub } \\
\text { karta) }\end{array}$ & $\begin{array}{c}\text { Płatne w biurze (gotówka } \\
\text { lub karta) lub w } \\
\text { pojeździe (gotówka) }\end{array}$ \\
\hline $\begin{array}{l}\text { Częstotliwość } \\
\text { kursowania }\end{array}$ & dowolna & dowolna & 4 kursy w ciągu dnia & $\begin{array}{c}\text { do } 6 \text { kursów w ciągu } \\
\text { dnia }\end{array}$ \\
\hline Punktualność & $\begin{array}{l}\text { Uzależniona } \\
\text { od } \\
\text { warunków } \\
\text { drogowych }\end{array}$ & $\begin{array}{l}\text { Uzależniona od } \\
\text { warunków } \\
\text { drogowych }\end{array}$ & $\begin{array}{l}\text { Niezależna od } \\
\text { warunków drogowych }\end{array}$ & $\begin{array}{l}\text { Uzależniona od } \\
\text { warunków drogowych }\end{array}$ \\
\hline $\begin{array}{l}\text { Przewóz osób } \\
\text { niepełnosprawnych }\end{array}$ & Tak & $\begin{array}{l}\text { Tak (usługa na } \\
\text { telefon) }\end{array}$ & Tak & $\mathrm{Nie}$ \\
\hline
\end{tabular}

Source: own compilation [10] 


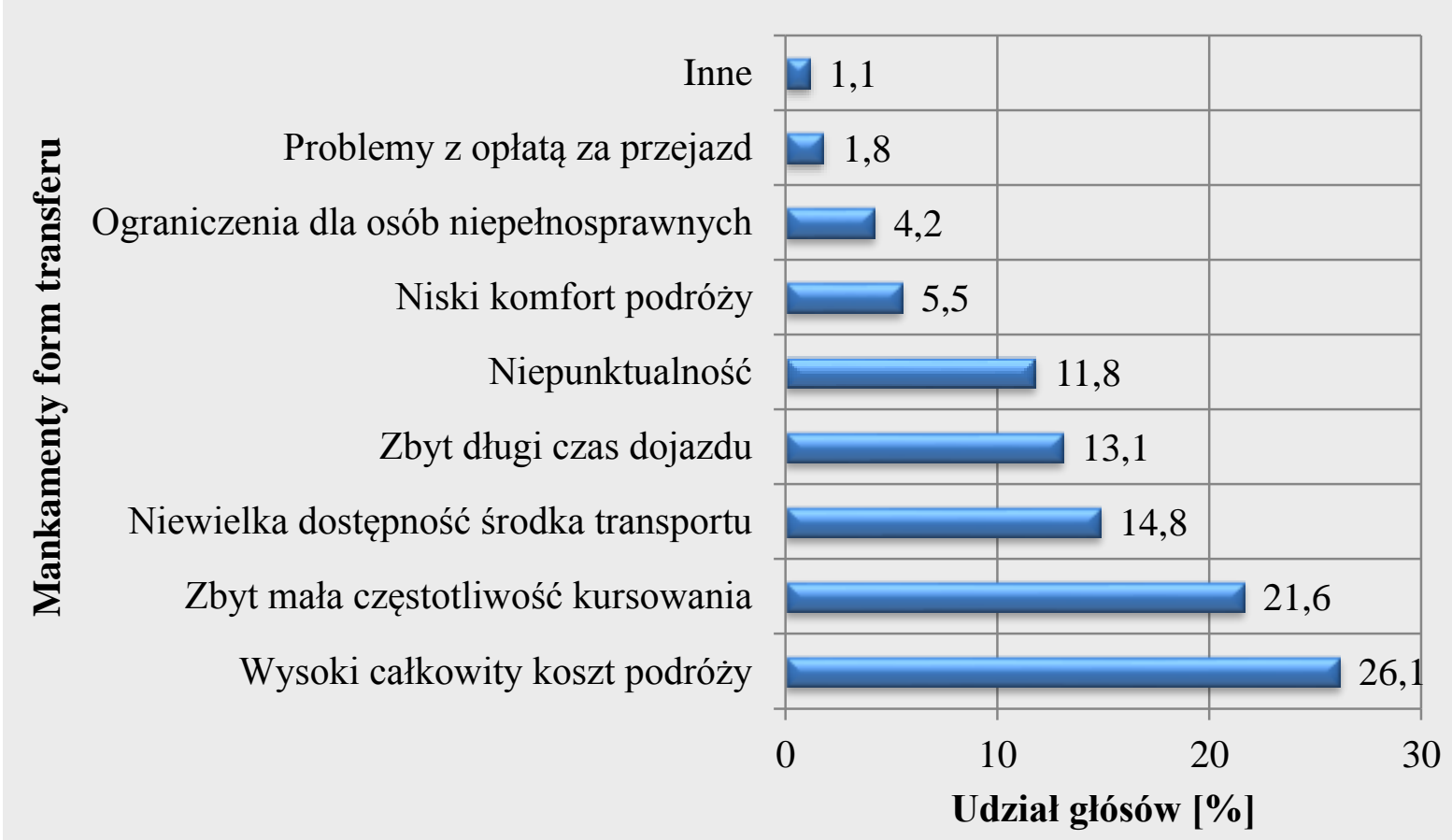

4. Disadvantages of used forms of commuting Source: own compilation

In road transport, punctuality depends largely on the congestion that occur during peak traffic. This problem does not concern only passengers choosing rail. An additional advantage is the rolling stock, because the carrier Regional Transport Sp. Z o.o. purchased vehicles adapted for transporting people with disabilities and limited mobility. An example may be a Diesel Multiple Units type Pesa Atribo (219m), which are equipped i.a .: low floor part, which is located at a height of $600 \mathrm{~mm}$ above the head of track, wide entrance, manual ramp, space for wheelchairs, adapted cabin WC, visual and acoustic passenger information system [4]. A similar comfort is offered in rail buses type PESA 214m (figure 5). In addition, passengers with the requisite powers and accompanying persons can take advantage of concessionary journeys and for their disposal was given comprehensively prepared platforms of the railway station, including a stop at the Airport Szczecin Goleniów (Figure 6). In this regard, much worse have road hauliers, who have only high floor rolling stock. Another difficulty is a form of tolls, which the driver can make only with cash. 


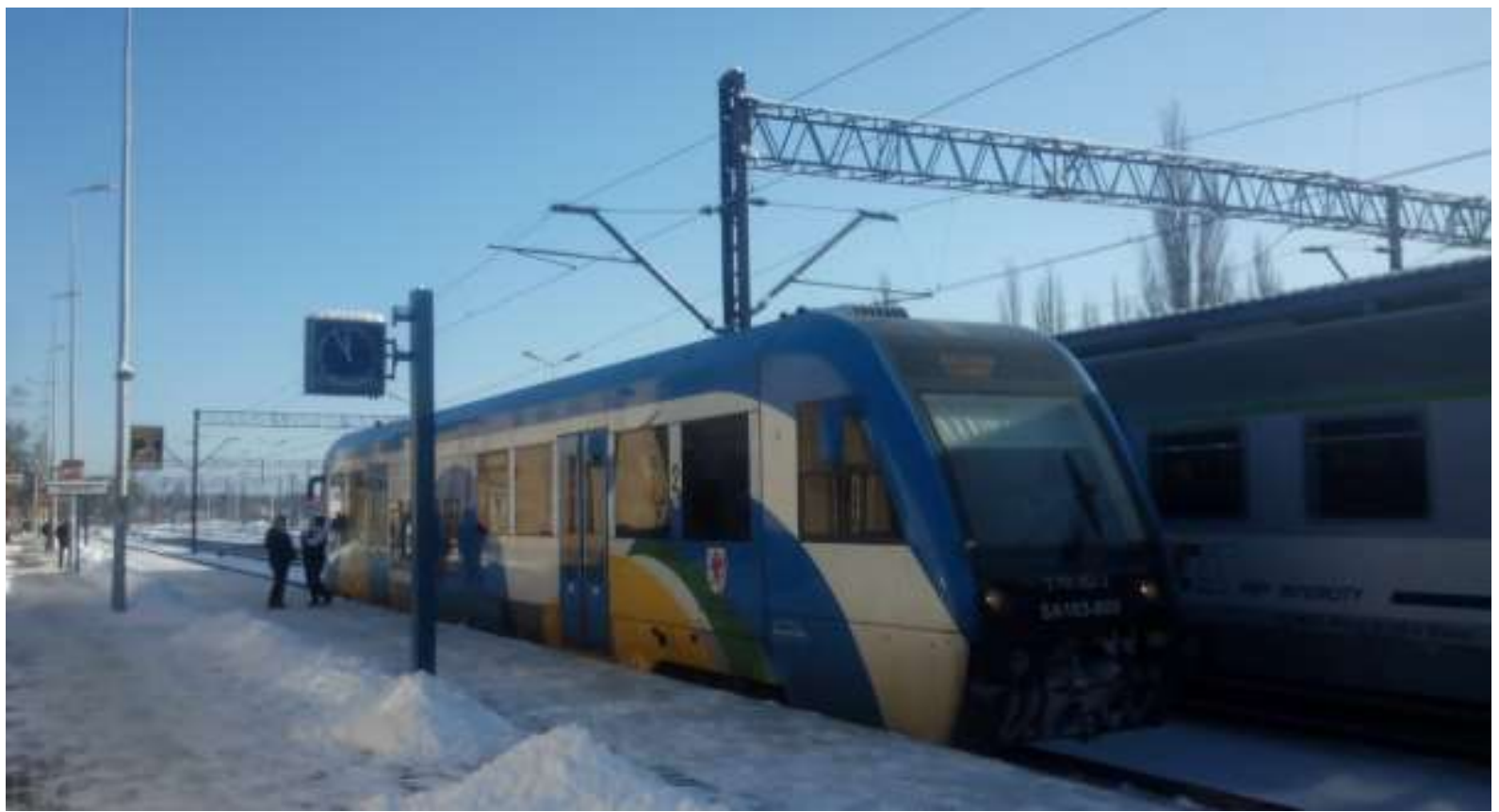

5. Railbus PESA 214m (series SA103-008) at an intermediate station Szczecin Dąbie Source: own compilation

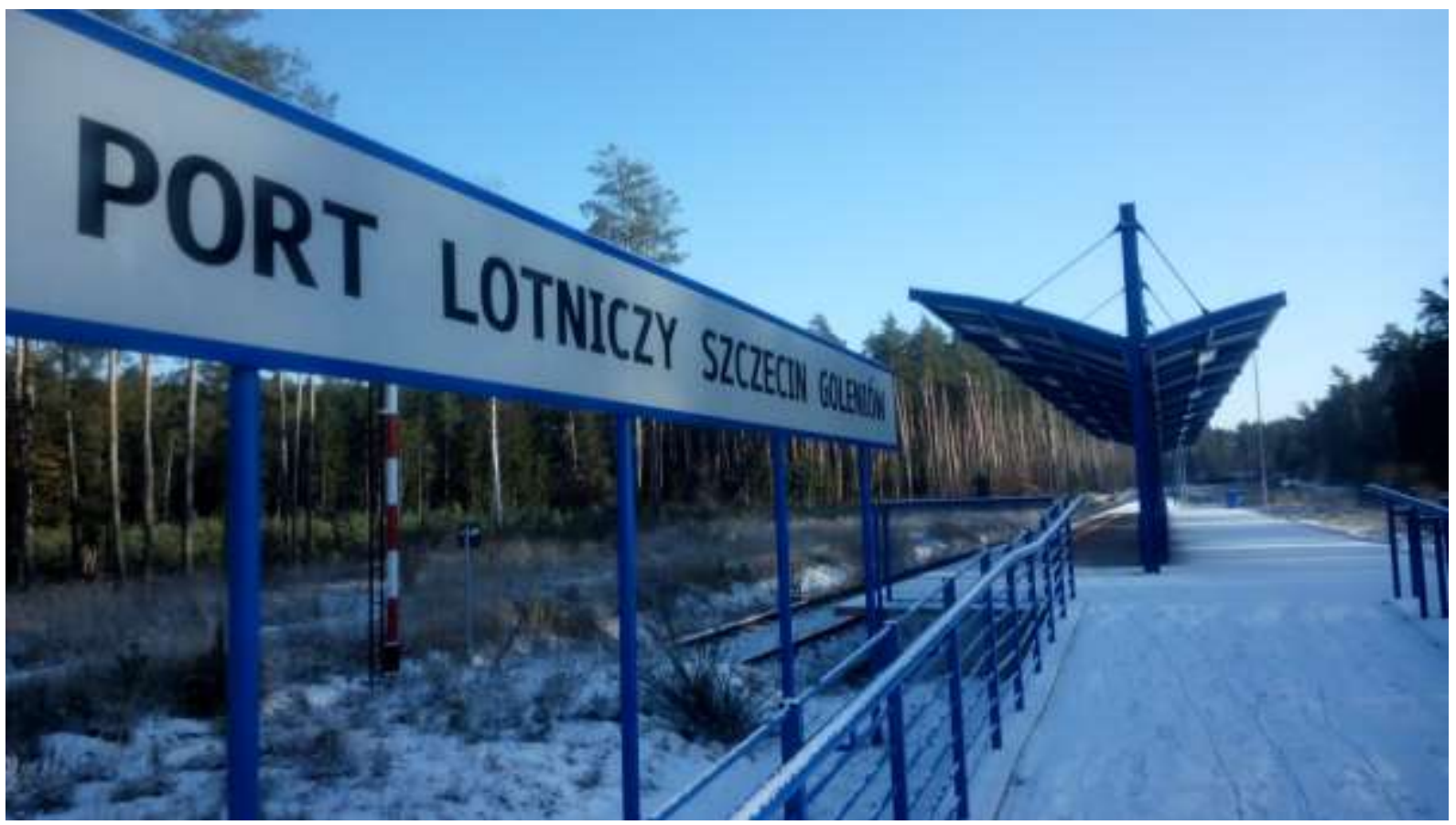

6. Rail stop Airport Szczecin Goleniów

Source: own compilation

\section{Passenger expectations}

In response to another question, respondents indicated that they expect in the aspect of improving access from / to the airport (Figure 7). By far the most frequently raised was the issue of the construction of the crossing between the road junctions Police - Goleniów, the key investment would be a hollow tunnel under the Oder to the Holy See and its combination with the West Road workaround Szczecin (Figure 8). The undeniable benefits of this solution include i.a .: relieving the city from vehicular traffic, improving access to seaports and air transport, improving communication between neighbouring municipalities and the entire 
region, including the areas of investment, border crossings and ferries. Unfortunately, the protracted decision-making processes and the lack of unequivocal declarations positions of the government indicates that in the coming years, the realization of this concept will remain only in the sphere of planning. In addition, the completion require other, no less important for the inhabitants of projects, e.g. ring road, whose construction began in 1998, as well as Szczecin Fast Tram (SST) reaching the Prawobrzeże. Unfortunately, his first step is not in any way integrated with the existing railway system by which passengers cannot use the intermediate stations in getting to the airport Szczecin-Goleniów. From other demands of the most frequently mentioned were: a reduction in parking fees at the terminal (21.3\%), the need for coordination of existing connections (16.5\%) and increasing the frequency of running public transport vehicles $(12,6 \%)$.

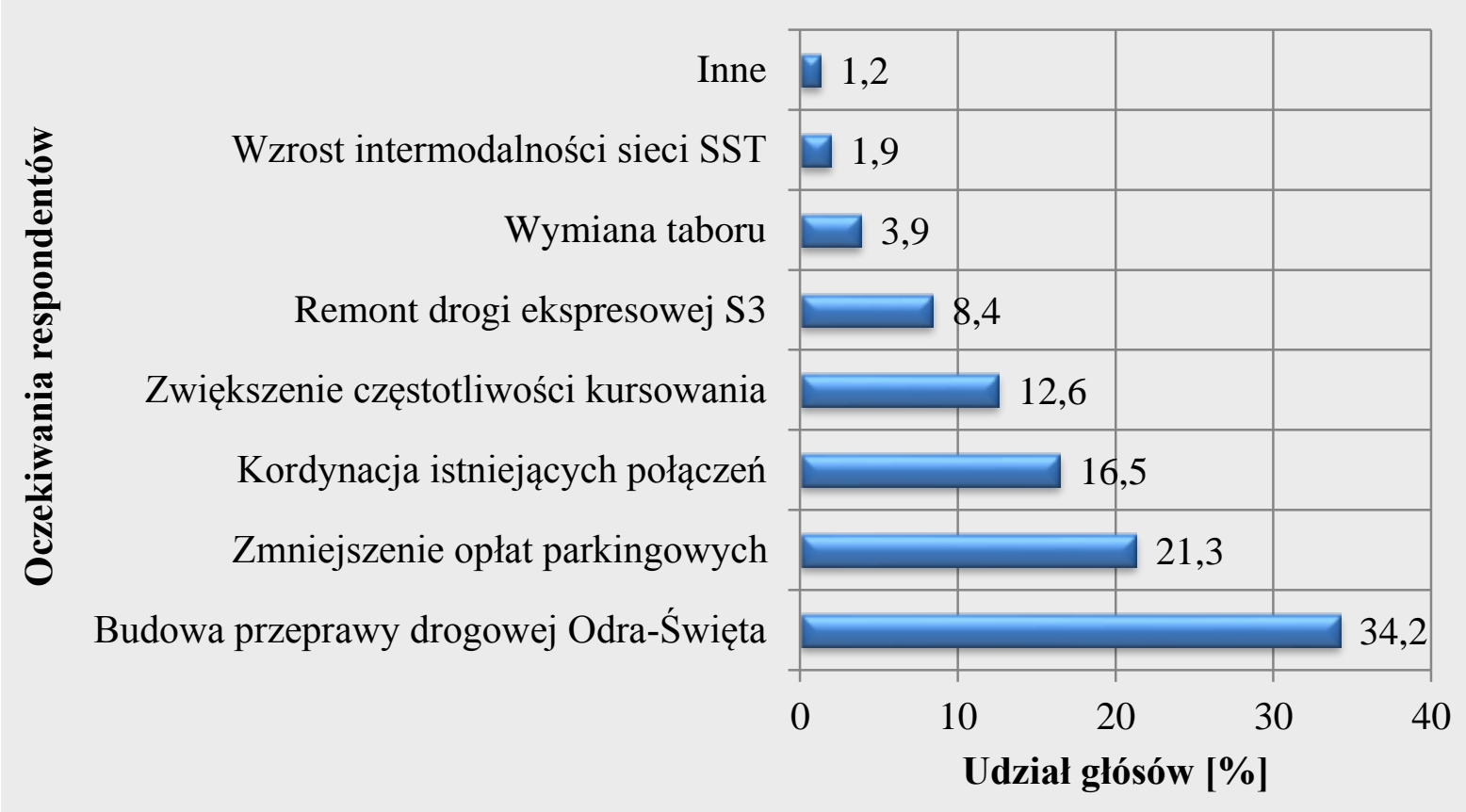

7. Expectations of respondents commuting from / to airport Szczecin-Goleniów Source: own compilation 


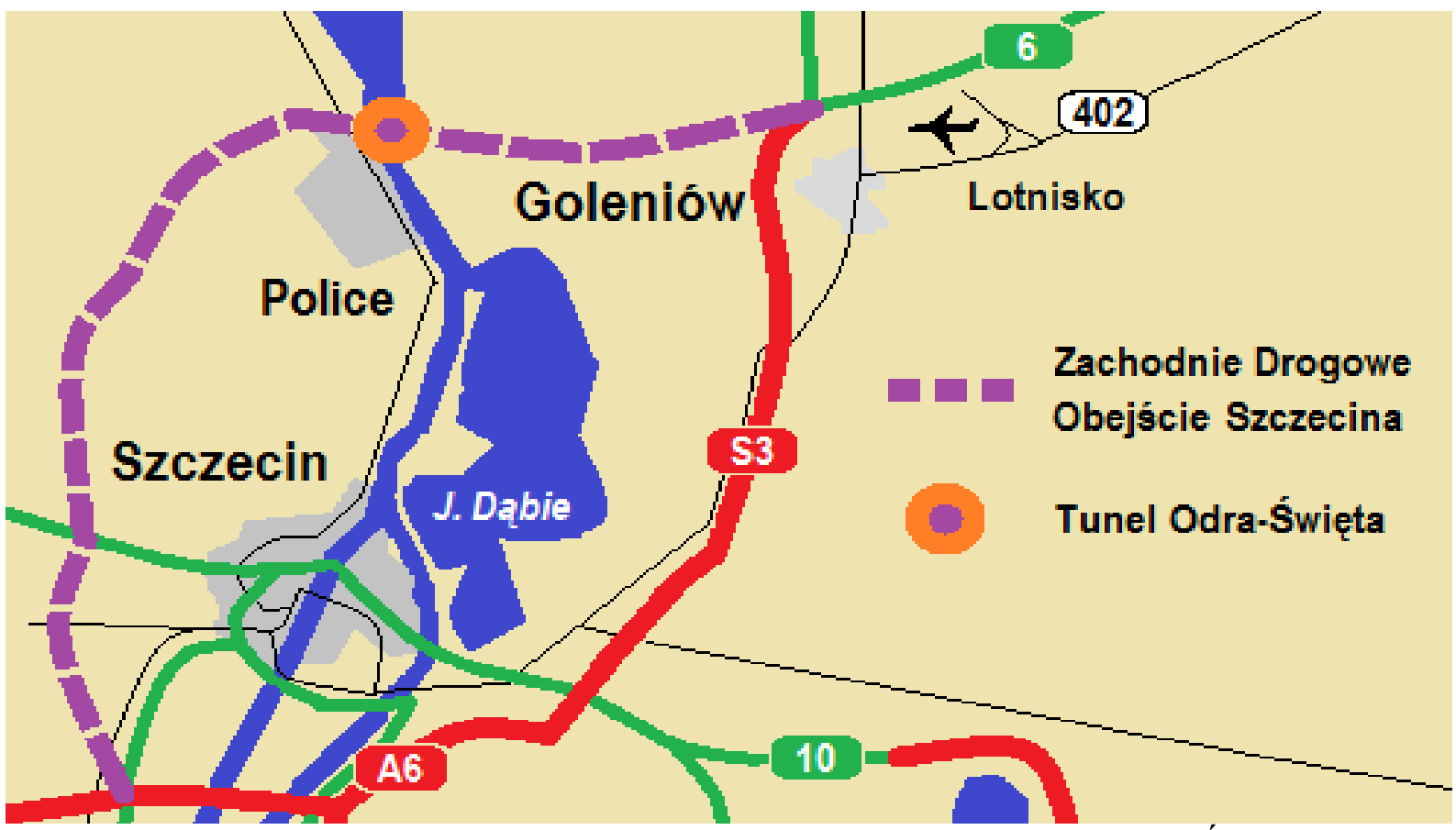

8. The concept of the West Bypass Road Szczecin crossing the Oder-Święta Source: own compilation

\section{Summary}

The conducted questionnaire allowed to extract the most important decision-making preferences and behaviour of passengers commuting to / from airport Szczecin-Goleniów. The results indicate that over the next years, the basic form of access will be private car. The increase in demand for other means of transport requires the presentation of a competitive transport service, devoid of the current difficulties and inconvenience. A major step in this direction was the launch rail, which carrier offers cheap calls and rolling stock adapted to modern standards. Unfortunately, the existing route network and low-frequency, they can not constitute an interesting alternative for travellers. This is evidenced by the demands made by respondents who primarily expect new investments in road infrastructure. For these reasons planning, construction and efficient management of the transport system requires coordination and cooperation of many entities, including i.a.: state and local administration, questionnaires private carriers, tour operators. In addition, combining various branches of transport in the so called multimodal centers favours not only rational and effective distribution of passenger traffic, but also gives you the opportunity to increase turnover in freight. In both cases, significant benefits can bring further economic development of the region, which undoubtedly influenced by newly established companies operating within the administrative borders of Szczecin, but also in the area of industrial parks (Goleniów, Police, Stargard).

\section{Source materials}

1. Drożdż W., Konieczyński P.: Regionalny transport lotniczy w województwie zachodniopomorskim. Infrastruktura Transportu 2/2009.

2. Falkowicz K., Nieoczym A.: Problemy logistyczne transportu pasażerów z centrum miasta do portu lotniczego. Logistyka 2/2014.

3. Huderek-Glapska S.: Port lotniczy w systemie transportu intermodalnego. LogForum, Vol. 6, No. 5, 2010.

4. Jędrzejewski B.: Spalinowe zespoły trakcyjne serii SA136. Świat Kolei 7/2011.

5. Kwan J.: Access to the skies. 12th International Conference on Mobility and Transport for Elderly and Disabled Persons (TRANSED), 2-4 June, Hong Kong 2010. 
6. Mańkowska M., Mańkowski T.: Możliwości integracji transportu kolejowego i lotniczego na przykładzie Portu Lotniczego Szczecin-Goleniów. Zeszyty Naukowe Uniwersytetu Szczecińskiego. Problemy Transportu i Logistyki, Nr 22 (778), 2013.

7. Olipra Ł.: Inwestycje $\mathrm{w}$ infrastrukturę lotniczą jako czynnik rozwoju gospodarczego miast i regionów. Acta Universitatis Lodziensis. Folia Oeconomica 246, 2010.

8. Praca zbiorowa zespołu Biura Strategii Urzędu Miasta Szczecin: Szczecin 2014. Raport o stanie miasta. Wydawnictwo "Butterfly", Szczecin 2014.

9. Shafabakhsh G., Hadjihoseinlou M., Taghizadeh S. A.: Selecting the appropriate public transportation system to access the Sari International Airport by fuzzy decision making. European Transport Research Review 6/2014.

10. Zieliński K.: Ocena dostępności Portu Lotniczego Rzeszów-Jasionka dla mieszkańców miasta Rzeszowa. Zeszyty Naukowe Uniwersytetu Szczecińskiego. Problemy Transportu i Logistyki, Nr 28 (843), 2014.

11. http://www.airport.com.pl. 